\title{
Book Availability Revisited: Turnaround Time for Recalls versus Interlibrary Loans
}

\section{David J. Gregory and Wayne A. Pedersen}

\begin{abstract}
Librarians typically view interlibrary loan (ILL) as a means of providing access to items not owned by the local institution. However, they are less likely to explore ILL's potential in providing timely access to items locally owned, but temporarily unavailable, particularly in the case of monographs in circulation. In a two-part study, the authors test the assumption that, on average, locally owned books that a patron finds unavailable (due to checkout) can be obtained more quickly via recall than via ILL. Phase 1 of this study establishes an average turnaround time for circulation recalls in a large academic library for comparison with wellestablished turnaround times for ILL borrowing transactions. In Phase 2 , a more rigorous paired study of recalls and ILL compares the ability of each system to handle identical requests in real time. Results demonstrate that, under some circumstances, ILL provides a reasonable alternative to the internal recall process. The findings also underscore the need for more holistic, interservice models for improving not just access, but also the timeliness of access, to monograph collections.
\end{abstract}

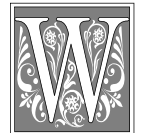

hen asked to shortlist the defining issues in our profession during the 1990s, many librarians would include what some called the "access-versus-ownership" debate and what others dubbed the access-ownership continuum. Regardless of one's perspective, it is interesting to note that over the past dozen years, the entire access-ownership dialogue has focused largely on the relationship between local collection development (ownership) and interinstitutional resource sharing (access). This dialogue has been so rich, multifaceted, and useful to librarians that it is difficult, at first, to notice what has been missing from the equation. If the ultimate goal is to connect patrons with information, efficiently and cost-effectively, librarians need to optimize and synchronize not only collection development and resource sharing, but also local circulation policy and practice. Despite the librarian's best efforts-now more informed than ever-to purchase the right material and to borrow the rest, a small voice in the book stacks can still be heard to complain: "But the good books are still never available when I need them."

David J. Gregory is Associate Dean for Research and Access at Iowa State University Library; e-mail: dgregory@iastate.edu. Wayne A. Pedersen is Head of Interlibrary Loan/Document Delivery at Iowa State University Library; e-mail: wap5@iastate.edu. 
There is little research, but plenty of anecdotal evidence, to support this claim. Michael Rogers showcased the problem in a recent "How do you manage?" column in Library Journal, a useful barometer of work in the field. ${ }^{1}$ In the results of a recent satisfaction survey at UC/ Berkeley's Moffitt Library, Patricia Davitt Maughan heard the message loud and clear from faculty and graduate students alike: "I rarely find the books I want on the shelves." 2 Those librarians who have not heard this comment directly need only consult with the staff at their circulation desks or check local statistics on the volume of recall activity. At the Iowa State University (ISU) library, where overall circulation statistics continue to drop (down 37\% over the past four years), the number of recalls processed annually has increased by 17 percent over the same time period.

The growing volume of recalls at this precise stage in our history when the average academic library can afford to purchase fewer and fewer monographs led the authors to ponder: How, and how well, is the library responding to the needs of those who fail to find on the shelf an item that the library already owns? ${ }^{3}$ In the case of the ISU library, the practice has been to recall the item if it is checked out to another reader and to borrow the item via interlibrary loan (ILL) only if it is missing, billed as lost, or at the bindery. The assumption behind this policy, and the justification for not routinely using ILL to borrow titles checked out to the library's own patrons, is that ISU librarians can certainly arrange for the sharing of one "owned" book between two local borrowers more quickly than they can fulfill the typical interlibrary loan.

This certainly appeared to be true in the past when ILL was considered by many to be an ancillary service, if not the last resort of a highly specialized clientele. Today's ILL office is likely to be a hub of activity and a focal point in library planning, programming, and funding. Circulation services have likewise evolved considerably in the past twenty years, due largely to automation. However, circulation policy appears to be surprisingly static in many academic libraries, governed principally, as one author has observed, by inertia. ${ }^{4}$ Certainly, advances such as online circulation systems and electronic messaging have streamlined the mechanics of the recall process, thus shortening the potential turnaround time between patrons. But circulation policy can still work to contravene this progress-policy that ensures, for example, a guaranteed minimum loan period for the original borrower or specified lengths of time that a recalled item must remain on a "hold" shelf, awaiting pickup. For precisely this reason, and with no hard data to confirm this, the authors suspected that little real progress had been made in reducing the turnaround time for library recalls. The average patron recalling an item checked out within the ISU library system is told that the process takes a few weeks, and this message has not changed significantly in what may be decades of service.

All of which prompts the question: How does recall turnaround time, which the authors suspect has remained relatively static, now compare to ILL turnaround time, which seems to have improved considerably in the past ten years? And does the answer to this question suggest changes to be made in any library's multipronged approach to improving the ready availability of books?

\section{Literature Review}

\section{Recall Performance and Book Availability}

Circulation, perhaps the least glamorous library operation, is notoriously underdocumented. Its status and visibility have improved over the past twenty years, coincidental with the emergence of Access Services departments, but there remains little published scholarship on the topics of circulation policy, practice, and (above all) performance. Compounding this problem is the idiosyncratic nature of circulation terminology. Most libraries, for example, provide some mechanism for alerting one borrower that 
another borrower needs the book he or she has taken out. Depending on the institution and the circumstances involved, this transaction might be considered a recall, a request, a hold, a save, a reserve, or a borrowing queue (although recall seems to be the preferred term in U.S. academic libraries). Terminology issues aside, library literature pays little direct attention to circulation in general or the recall function in particular. Obliquely, however, the topics have been addressed in a rather sizeable body of literature focusing on book availability-a popular theme throughout much of the 1970s and 1980s.

In his 1975 landmark Book Availability and the Library User, Michael H. Buckland was one of the first to explore in depth the "essentially logistical problem of making library books physically available when wanted by library users," and to assess the impact of acquisitions, discarding, binding, circulation, and duplication on this process. ${ }^{5}$ Based on the growing evidence that "a large amount of the demand for books tends to be concentrated on a small proportion of the library's stock," Buckland focused largely on the problem of managing heavily used books, which requires a harmony of policy and practice across these five core activities, adjusting such factors as loan period and number of copies. 6 Unfortunately, Buckland did not specifically address the impact of recalls on book availability, saying merely that they play an ambivalent role in stock management and are "singularly time-consuming in terms of labour."7

In his own studies at the University of Lancaster, Buckland had demonstrated that the most likely inhibitor to the immediate availability of books was the fact that requested items were on loan. Other writers and researchers went further to demonstrate just how serious this problem was. Daniel Gore's assessment of the situation at Macalaster College Library was perhaps the most trenchant. ${ }^{8}$ Through a study of one thousand efforts by students to find books the library owned, Gore determined that the average failure rate was roughly 42 percent. His conclusion that "a well-stocked, wellsupported, and allegedly well-balanced library can routinely thwart its users on nearly half their requests," was in turn frequently cited by others who sought to discover how their own libraries measured up. 9

Comparable research emerged from the Case Western Reserve Library (CWRL) at about the same time, with useful studies by Paul B. Kantor, Tefko Saracevic, and William M. Shaw. ${ }^{10}$ Kantor is credited with being the first to illustrate, through the use of a branching diagram, the cumulative probability that a patron will find a book on a library's shelves, depending on his or her success in clearing four separate barriers: that the item has not been acquired by the library, that the item is circulating, that the library has made a mistake (such as misshelving), or that the patron has erred (perhaps misreading a call number). Using this technique, Saracevik, Shaw, and Kantor demonstrated that, in 1972, when a semester loan policy was in effect at CWRL, 23 percent of all books requested by patrons (and known to be owned by the library) were on loan. By 1974, when the semester loan policy had been strategically replaced by a four-week loan period, this figure had dropped to 13 percent. ${ }^{11}$ Thus, a change in loan period was shown to significantly improve one of the four factors-circulation performance-in the library's overall book availability rating. Interestingly, when the additional effects of acquisition, library, and patron errors were factored in, overall book availability rates at CWRL were 48 percent in 1972 and 56 percent in 1974- "success" rates as surprising as those previously cited by Gore.

By the time John Mansbridge published his 1986 review article, "Availability Studies in Libraries," Kantor's branching technique had become the standard method for analyzing book availability, although a variety of other techniques were employed. ${ }^{12}$ Mansbridge examined 
more than forty studies, widely divergent in focus, setting, and methodology, to report that overall immediate availability ranged from 8 percent to 89 percent. However, when he narrowed his focus to twenty-one studies that had some commonality (for example, measuring the availability of monographs only, using patron-driven requests in open stack libraries), Mansbridge found the average availability rate to be 61 percent. ${ }^{13}$ Not surprisingly, "materials in circulation" and "library error" were the largest source of nonavailability, at least in academic libraries. ${ }^{14}$ Again, Mansbridge emphasized that, in general, "a user going to a library for an item may have only a $60 \%$ chance of getting the item even if the library owns it." 15

Since Mansbridge's review, libraries have continued to assess immediate book availability, frequently using Kantor's technique. Terry Ellen Ferl and Margaret G. Robinson reported an overall 61 percent availability rate at UC/Santa Cruz in 1986, with 35.5 percent of all failures resulting from titles on loan. ${ }^{16}$ Three separate studies of material availability have been published by librarians at the William Patterson College Library (WPCL). In 1987, Anne C. Ciliberti and others reported a 54 percent overall availability rate, with 25 percent of the failures resulting from titles on loan. ${ }^{17}$ Eugene S. Mitchell and others repeated the study at WPCL in 1989, after implementing recommendations aimed specifically at remedying circulation, patron, and selection errors (for example, improving signs, purchasing duplicate copies of high-demand books, and enhancing bibliographic instruction).$^{18}$ Overall book availability increased to 64 percent, although 22 percent of the failures still resulted from titles being on loan. ${ }^{19}$ A still later study by Ciliberti and others looked more broadly at the availability of books and periodicals, using an expanded version of Kantor's branching technique, but comparing results with OPAC transaction logs, to explore their potential for unobtrusive study of search and retrieval fail- ures. ${ }^{20}$ Book availability was calculated at 62 percent, with 31 percent of failures resulting from items being on loan. ${ }^{21}$

Inspired, in part, by reports from William Patterson College Library, N. A. Jacobs conducted a pair of similar studies at the University of Sussex Library in 1994, measuring book availability before and after the implementation of strategic policy changes. Overall availability rose from 62.5 percent to 71.7 percent, but the largest single reason for the unavailability of books continued to be that they were on loan. ${ }^{22}$

Although the literature amply demonstrates the magnitude and persistence of the book availability problem, as well as its occasional remediation (by purchasing multiple copies, adjusting loan periods, and so on), little attention has been paid to the impact of recall policy, practice, and performance in this service area. The reason is simple: Almost all the major studies have focused on the question of immediate availability, rather than on the cumulative availability rate for materials measured over time. Robert Goehlert made this distinction in back-to-back articles in 1978-1979, reporting the results of studies at Indiana University (IU), which are unique in their focus on the recall function. ${ }^{23}$ Goehlert's initial study, conducted in 1974-1975, found that only 48 percent of all books requested by faculty via a campus delivery service (and known to be owned by the library) were immediately available. One-third of all requested books were unavailable because they were on loan. (Other factors in unavailability included "being reshelved" and "on search.") The originality of Goehlert's study, however, is his calculation of cumulative availability over time. After one week, as recalls, searches, and reshelving were gradually fulfilled, availability had risen to 59 percent, and after two weeks, to 73 percent. In the specific case of recalls, Goehlert demonstrated that had all books been returned from recall within fourteen days, the cumulative availability rate at two weeks would have been not 73 percent, but 84 
percent. In a follow-up study, Goehlert meticulously examined 2,000 recalled books within IU's main collection, representing 17 percent of all recalls for 19751976. Results demonstrated that undergraduate and graduate students returned recalled books within 5.91 and 5.86 days, respectively, after a recall notice was sent, as opposed to faculty, who waited 17.07 days - a revelation that led administrators to institute recall fines for faculty. ${ }^{24}$ Goehlert's studies, and his attempts to index cumulative availability of heavily used items, made a useful contribution to the literature. Unfortunately, this particular thread of the book availability discussion engendered no subsequent research.

\section{Interlibrary Loan}

Unlike the performance of recalls, which has received scant attention in the context of book availability studies, the performance of ILL has been scrutinized closely for many years, and performance indicators are well established. In his 1985 review article, Thomas J. Waldhart summarized four measures commonly used to evaluate ILL performance:

- Success rate, also known as "fill rate," measures successfully filled ILL requests as a percentage of total requests received and is applied to both borrowing and lending operations.

- Turnaround time is the amount of time it takes-usually in days-for an ILL request to be fulfilled. (This is typically monitored by borrowing, but not lending, operations.)

- Cost is the actual, per transaction cost of both borrowing and lending operations, as determined by internal cost studies.

- Impact on service refers to patrons' perception of service quality and is normally applied only to borrowing transactions. ${ }^{25}$

In April 2001, Joan Stein published an update to Waldhart's paper, reviewing ILL performance studies for the years 1986 to $1998 .{ }^{26}$ Her four categories were similar but used slightly different terminology:
- fill rate and reasons for failed requests;

- turnaround time and the impact of delivery methods;

- cost studies;

- user satisfaction studies.

Despite the growing agreement on performance indicators for ILL, researchers have calculated turnaround time in a variety of ways, making comparisons difficult at best. Stein confirmed this situation, writing: "Turnaround time, or speed of supply, is perhaps the most widely used and widely divergent performance measure of ILL and document supply." ${ }^{27}$ Table 1 lists eight recent studies of turnaround time that substantiate this divergence. ${ }^{28-35}$ The majority of these studies count the number of days required for internal processing (from the date the borrowing library orders an item until the date the item is available for pickup by the borrowing patron), with times ranging from roughly five to thirteen days. In other studies, however, researchers choose alternative start and stop points: the former including the date the borrowing patron submits his or her request, and the latter including the date a lending library ships an item or the date the borrowing patron actually retrieves an item for checkout. In the single reported study that examined turnaround time from the "outer limits" of patron perception (from the date the patron submitted a request to the date the patron retrieved the requested item), turnaround time varied from 8.4 days at one library to 15.4 days at another.

Turnaround time is influenced, of course, not only by start-stop parameters, but by other factors as well. One is the number and types of libraries studied. Mary E. Jackson's study of 119 college and research libraries is the largest to date. Linda L. Phillips studied twenty-five multitype libraries. Studies by Mary K. Sellen, John Budd, and Kimberly L. Burke each focused on a single library. The type of material requested (returnable versus nonreturnable) can influence turnaround time as well, as evidenced by Burke's analyses. 


\begin{tabular}{|lcc|}
\hline \multicolumn{3}{|c|}{ TABLE 1 } \\
Studies Documenting ILL Turnaround Time \\
\hline \hline Method of Calculation & Author & Average \# of Days \\
\hline Date ILL staff requested to date ILL received & $\begin{array}{c}\text { Sellen (1999) } \\
\text { Budd (1986) }\end{array}$ & $\begin{array}{c}12.79 \\
\text { Phillips (1999) }\end{array}$ \\
& $\begin{array}{c}7.20 \\
\text { Burke prestudy } \\
(1999)\end{array}$ & $\begin{array}{c}12 \text { loans } \\
9.8 \text { copies }\end{array}$ \\
& $\begin{array}{c}\text { Burke poststudy } \\
(1999)\end{array}$ & $\begin{array}{c}\text { \& loans } \\
6.6 \text { copies }\end{array}$ \\
\hline Date ILL staff requested to date patron received & $\begin{array}{c}\text { Weaver-Myers, } \\
(1996)\end{array}$ & 15.46 \\
\hline Date patron requested to date patron notified & Jackson (1998) & $\begin{array}{c}14.9 \text { research \& } \\
9.5 \text { college }\end{array}$ \\
\hline Date ILL staff requested to date shipped by lender & Medina (1988) & 9 \\
\hline Date patron requested to date ILL received & None reported & \\
\hline Date patron requested to date patron received & Levene (1996) & $\begin{array}{c}8.4 \text { at one library \& } \\
15.4 \text { at another }\end{array}$ \\
\hline
\end{tabular}

A subset of Jackson's data on ILL performance in ninety-seven research (versus college) libraries is of special interest to the present study and can be summarized as follows:

- borrowing cost per transaction: \$18.35;

- lending cost per transaction: $\$ 9.48$;

- borrowing turnaround time: 15.6 days;

- borrowing fill rate: 85 percent;

- lending fill rate: 58 percent;

- patron satisfaction levels: 94 to 97 percent. ${ }^{36}$

If interlibrary loan is to serve as a substitute for local ownership, turnaround time must appear reasonable to patrons. Waiting 15.6 days to receive an item on ILL may appear unreasonably long, but the high patron satisfaction rates reported by Jackson would suggest that this was not a major consideration of patrons surveyed. Indeed, Jackson correlated the various ILL measures of performance with patron satisfaction and found the strongest correlations to be with (1) payment and (2) interactions with ILL staff. This corroborates earlier reports by Pat
L. Weaver-Meyers that patron satisfaction correlates strongly with the patron's perception of timeliness, but not with the actual delivery speed. ${ }^{37}$ In short, ILL patrons are perhaps more tolerant of delivery speed than has been assumed by ILL practitioners and library administrators.

Focusing exclusively on book loans (as opposed to photocopies), a turnaround time of nine to seventeen days appears to be the norm. Johanna E. Tallman documented an average of eleven days in 1980; A. T. Dobson, P. P. Philbin, and K. B. Rastogi, 11.5 days in 1982; Jackson, seventeen days in 1998; and Burke a mere 9.1 days in 1999 (with efficiencies achieved via work-flow adjustments).$^{38}$ For the purposes of this paper, when referring to ILL service, the terminology established by Maurice Line will be adopted. ${ }^{39}$ "Turnaround time" will refer to the library perspective and indicate the calendar days elapsed from the date the borrowing library requests an item to the date the borrowing library receives it. "Satisfaction time" will refer to the patron's perspective and indicate the calendar days elapsed from the date the pa- 
tron requests an item to the date the patron receives it.

\section{Research Hypothesis}

The ISU library has tracked ILL turnaround time for several years, both independently and as part of cost/performance studies coordinated by the Association of Research Libraries (ARL) and the Greater Western Library Alliance (GWLA). Internal data show the average turnaround time for book loans at ISU ranging from nine to eleven days over the past three years, calculated from the date the material is ordered by ILL to the date the material is received in ILL. This is consistent with (and on the lower end of) figures in the literature. The ISU library has never tracked recall turnaround time. The present study tests the hypothesis that, on average, books that a patron finds locally unavailable can be obtained more quickly via recall than via ILL.

\section{Institutional Background}

A brief description of the ISU library's collections and services provides a backdrop for the current study. With 2.2 million volumes and 20,000 current serial subscriptions, the library grows at a rate of 40,000 volumes per year but seldom acquires more than one copy of any monograph (except for course reserves). Faculty, graduate students, and professional staff can borrow most books for the entire academic year, making the timely recall of materials an absolute necessity. All other patrons receive a two-week loan. Any item in circulation is subject to recall when needed by another patron, regardless of the status of the original borrower or the requestor. A printed recall notice is mailed to the original borrower, establishing a new due date that guarantees a minimum two-week loan as well as a minimum seven days for notification and response, although these two minimums may overlap in whole or in part. There is no grace period for recalls, and all patrons-including faculty-are subject to a fine of one dollar per day for overdue recalls, up to a twenty-dollar maximum.
In the two calendar years of the study (2000 and 2001), library staff processed 18,973 and 17,951 recalls, respectively.

ILL borrowing service is available to faculty, undergraduates, graduate students, university staff, visiting scholars, and other affiliated patrons. Clio is used for data management by both the borrowing and the lending units; OCLC is used for ordering, whenever possible; and Ariel is the preferred method for delivering and receiving documents.

Like most research libraries, ISU has experienced exponential growth in its ILL borrowing service: in FY1992, some 6,499 items were borrowed from other libraries; by FY2002, this had increased to 15,169 . Staff were able to fill 95 percent of the borrowing requests initiated by patrons in FY2002. Returnables such as books, microfilm, and videotapes accounted for 30 percent of all items borrowed that year.

The library participates in a number of consortial ILL agreements providing free exchange of documents and returnables. Most agreements include a provision for expedited delivery. As a member of the GWLA and the Iowa Regents Interinstitutional ILL Group, the library relies heavily on partners in both consortia. Most documents are exchanged via Ariel, whereas returnables are sent via commercial shippers such as Fedex, UPS, and Airborne. The library also participates in the State of Iowa Access Plus program, which provides free ILL service among multitype libraries in the state but does not include expedited delivery provisions. Customized holdings groups in OCLC allow the librarians to maximize their interaction with "preferred partner" libraries (those in close proximity, those using Ariel for document supply, or those using expedited courier services).

\section{Phase 1: Unpaired Study of Recall and ILL Turnaround Times Methodology}

The goal of phase 1 was to determine average turnaround and satisfaction times for a recall in the ISU library system, adopt- 
ing the terminology used in the ILL literature. For each recall examined in phase 1, the authors tracked the number of calendar days elapsed from the date the recall was placed to the date the recalled item was returned to the library (turnaround time) and also the number of calendar days elapsed from the date the recall was placed to the date the patron actually retrieved and borrowed the requested item (satisfaction time). The former could then be compared with ISU's established ILL turnaround time of nine to eleven days; the latter could facilitate future comparisons with ILL satisfaction times.

October 2000 was selected for phase 1 review as a typical month in the academic calendar, unaffected by lengthy holiday or interim periods. Anticipating (from past experience) that staff in the main library would process roughly 2,000 recalls during the month, the study isolated every tenth recall processed, continuing until 200 recalls had been selected for analysis, resulting in a systematic sample of 10 percent of all recalls for the month. (Because there is no repeated or periodic structure within the total population of recalls processed in a month, a systematic sample with a random start point was seen as an effective alternative to a truly random sample.)

An Access $^{\mathrm{TM}}$ database (figure 1) was used to monitor the progress of each recall transaction, tracking the date an item was requested, along with the date it was returned by the original borrower and the date it was eventually checked out by the requestor (or, in some cases, the date the item "expired" on a hold shelf, waiting to be retrieved). Reports generated by the library's Horizon-based online circulation system provided all the necessary dates. Other fields in the Access record (borrower name and ID, item call number and bar code) permitted quick and accurate updating of the file from the daily Horizon reports. A separate field, labeled Queue, indicated whether a recall queue existed (that is, multiple simultaneous recalls on a given item) and what position the studied recall held in that queue.

\begin{tabular}{|c|}
\hline $\begin{array}{c}\text { FIGURE 1 } \\
\text { The Access }{ }^{\text {TM }} \text { Record Structure } \\
\text { for Phase } 1 \text { Study }\end{array}$ \\
\hline $\begin{array}{l}\text { Transaction number }(1-200) \\
\text { Requestor name } \\
\text { Requestor ID } \\
\text { Item call number } \\
\text { Item bar code number } \\
\text { Location in recall queue }(1,2,3 \text {, etc.) } \\
\text { Date item requested } \\
\text { Date item returned } \\
\text { Date item checked out by requestor } \\
\text { Date item expired on hold shelf }\end{array}$ \\
\hline
\end{tabular}

The default value " 1 " signified that at the time the recall was placed, no other recalls were pending on this item. A value of " 2 " signified that at the time the recall was placed, one other patron was already waiting in the recall queue for this item, and so on.

The progress of each recall was monitored throughout the fall 2000 semester until all recalls had been fulfilled, had been canceled by the requestor, or had expired.

\section{Results}

Data from the first phase of the study are summarized in table 2. Of the 200 items recalled, 196 were returned to the library an average 12.3 days after the recall request was made. One hundred fifty-four of the returned items were subsequently checked out by the requestor, an average 15.4 days after the request was placed. Forty-two of the returned items were never retrieved by their requestors, and four of the original 200 items were never returned by the original borrowers.

Focusing only on the 145 items with a recall queue of " 1 ," 144 of these items were returned to the library an average 9.6 days after the request was placed. Of these, 117 items were checked out by the requestor an average 13.3 days after the request was processed. Twenty-seven of the returned items were never retrieved by their requestors. Of the original 145 items, only one was never returned by the original borrower. 
Forty-six of the recalls in the study, almost a quarter of the total reviewed, were "second" recalls within a queue. Of these, forty-four were returned to the library an average 15.4 days after the request was placed. Thirty-two of the returned items were checked out by the requestor an average 19.5 days after the request was placed, and twelve returned items were never retrieved. Only one of the original forty-six items was never returned to the library.

Finally, eight of the recalls in the study were "third" recalls within a queue. All eight items were eventually returned to the library an average 42.5 days after the request was placed. Five of these items were eventually checked out by requestors an average 37.2 days after the request was placed. Three items, however, were never retrieved from the hold shelf. The one remaining recall in the sample proved to have an outstanding queue of " 7 " and had already been billed as lost, and was thus removed from the study.

\section{Phase 2: Paired Study of Recall and ILL Turnaround Times Methodology}

Phase 1 of the study provided an average recall turnaround time (12.3 days for all recalls, regardless of queue size; 9.6 days for "first" recalls in a queue) to be compared with ISU's preestablished average turnaround time of nine to

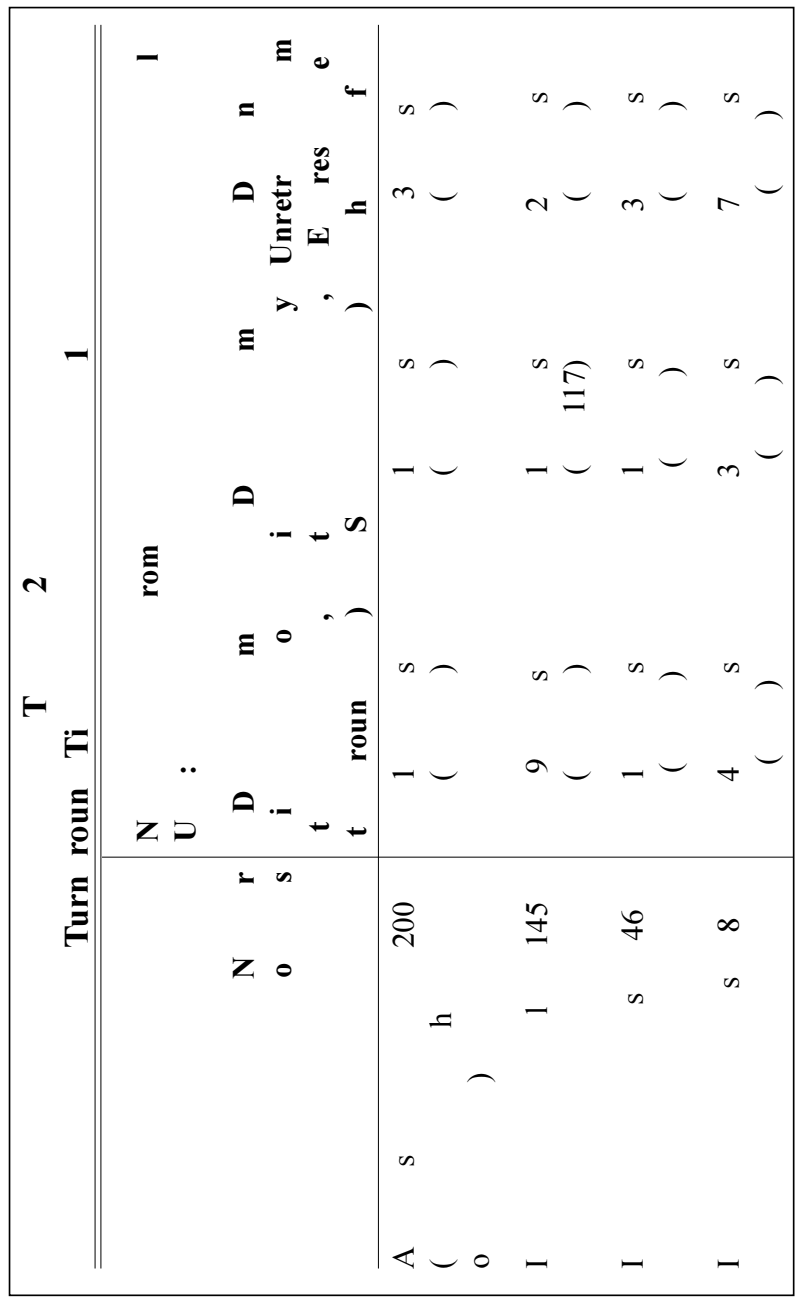
eleven days for ILL returnables. The samples compared in phase 1 , however, were obviously unrelated. In the second phase of the study, conducted in August 2001, thirty recalled books-chosen at random-were simultaneously requested via ILL to test actual turnaround time in a more rigorous paired study.

In the typical month of August, some 260 recalls are processed per week by staff at the library's circulation desk. The authors considered a sample of thirty titles (15\%), processed during the week of August 20-24, to be sufficient for this paired study. Titles were identified using a random number table, applied to the first 200 requests processed during the week. Circulation staff were given the list of thirty randomly selected numbers and pulled those requests from their work flow immediately after initiating each recall. Patron 
and bibliographic information for all thirty books was then forwarded to ILL staff, who promptly requested the items via OCLC the same day. Both the circulation recalls and the ILL requests were handled according to normal procedures, with no special attention other than to monitor three dates: (1) the date recalled or requested on OCLC; (2) the date the item was returned to circulation or checked in by ILL staff; and (3) the date each item was actually retrieved and checked out by the patron.

Each patron, initially aware only that he or she had placed a recall, was made aware of the supplementary ILL request by a standard e-mail message (figure 2). This memo explained the study and told the patron to expect separate availability notices from both the ILL and the circulation departments as copies of the requested book became available. Patrons were told they could retrieve either or both copies of the book, but that loan periods would differ between the ISU-owned copy and the copy received from another library. Patrons were not obligated to retrieve both copies of the book; however, they were asked to contact either circulation or ILL to let staff know if they no longer needed access to the copy in question.

\section{Results}

Results of the paired study are summarized in table 3, which provides for each item: the unique ID number (1-30), the random table number, the date requested, the number of days elapsed before the item was received by circulation/ILL (turnaround), and the total number of days elapsed before the patron retrieved the requested item from the library (satisfaction).

For example, the first item in the study was random item number 002 in the population of 200. This book was recalled by circulation staff on August 20, 2001, and requested by ILL staff via OCLC on the same date. The recalled book was returned to the circulation unit ten days later, sat on the hold shelf an additional seven days, to be retrieved by the patron after a total of seventeen days. The same book was received and checked in by ILL staff six days after being requested and sat on the hold shelf in ILL for two days, to be retrieved (by the same patron) after a total of eight days.

Two items were excluded from the study for technical reasons. In the first instance (ID\# 2), the request was cancelled by the patron between the time the recall was placed and the time the ILL copy was to be ordered. The second (ID\# 20) proved to be an ISU extension publication that was held only by the ISU library.

In looking at overall averages, the turnaround time for the remaining twentyeight recalls was 6.3 days, ranging from a low of one day to a high of twenty-two. All twenty-eight recalled items were eventually returned to circulation. Six of the recalled books were not retrieved by patrons because either the recall expired or the patron cancelled the request. In the twenty-two cases when patrons retrieved the requested item, the average total satisfaction time (from patron request to patron pickup) was 9.5 days.

The average turnaround time for ILL was one day longer than for recalls: 7.3 calendar days, based on data for twentyeight requests. The range was from a low of two days to a high of seventeen. The average satisfaction time for ILL was 11.8 days, based on only twelve of the thirty requests. Upon being notified by ILL staff that a book was available for pickup, many patrons said they already had the recalled copy and did not need the ILL copy. Other items were simply never retrieved and remained on the ILL hold shelf until they were returned to the lending library; presumably because the patron had already picked up the recalled book.

Given the low rate of pickup for ILL items, a strict comparison of the satisfaction time for each pair of requests is not likely to be meaningful. In fact, in only eight cases did the patron retrieve both the recalled copy and the copy obtained via ILL-a sample subset that might be described as "perfectly paired" (table 4). Nevertheless, it is possible to do a twotailed $\mathrm{T}$ test on the mean satisfaction times 
FIGURE 2

Memo to Requestor Regarding the Paired Recall/III Transactions

To:

From: Wayne Pedersen

Head, Interlibrary Loan/Document Delivery

Iowa State University Library

David Gregory

Acting Head of Access Services

Iowa State University Library

Subject: Recalled book

Date:

In response to comments received from several ISU library users, and with a view to improving library service, we are exploring the relationship between recalled books and interlibrary loan service, particularly with regard to "turnaround time."

On , you placed a recall for the following book at the Parks Library

circulation desk:

$<$ Call number; author; title $>$

Your request was randomly selected from recalls placed in the last few weeks, and, - in addition to recalling the book-,we have requested the book from another library via interlibrary loan. We are very interested in comparing the speed with which this book is made available to you through these two different services.

You will be notified separately when each of these books is ready for you to pick up. You then have the option of using one or both of them, depending on your need. If you choose not to use one of these copies, we ask that you contact staff at the appropriate service desk (i.e., circulation at 294-3961; or interlibrary loan/document delivery at 294-8073) and tell them you no longer need the material. Please be aware that the loan period you receive will vary between the ISU-owned copy and the copy obtained from another library.

Please contact Wayne Pedersen (198B Parks Library, 294-0440; wap5@iastate.edu) if you have any questions or concerns.

for this relatively small sample, producing the following results:

Sample size $=8$

Two-tailed $P$ value $=0.7843$

$\mathrm{T}=0.2845$

Standard error of difference $=3.515$

Mean of the recall group (11.75) minus

the mean of the ILL group $(12.75)=-1.0$

95 percent confidence interval of this difference: -9.31 to 7.31
By these criteria, the one-day difference between mean satisfaction times is not considered statistically significant.

Excluding the factor of patron response and focusing, instead, on the strict turnaround time for both recalls and ILLs, the two-tailed $\mathrm{T}$ test produces the following results:

Sample size $=28$

Two-tailed $P$ value $=0.3506$ 
$\mathrm{T}=0.9498$

Standard error of difference $=1.053$

Mean of the recall group (6.32) minus the mean of the ILL group $(7.32)=-1.00$

95 percent confidence interval of this difference: -3.16 to 1.16

Again, the one-day difference between the mean turnaround times for recall and ILL transactions is not considered statistically significant.

\section{Discussion}

Phase 1 of this study, focusing on 200 randomly chosen recalls, demonstrated that the average recall required 12.3 days for turnaround and an additional 3.1 days for pickup, making satisfaction time 15.4 days. The 15.4 days for patrons to obtain their materials compares closely with the average ILL/borrowing satisfaction time cited by Jackson in 1998 for ninety-seven research libraries (15.6 days) and compares favorably to Jackson's average satisfaction time for the borrowing of returnables (17 days).

It is more revealing, however, to compare the 12.3-day average recall turnaround time to Iowa State's own ILL turn-

\section{TABLE 3}

Turnaround Times for Paired Recall/ILL Transactions in Phase 2

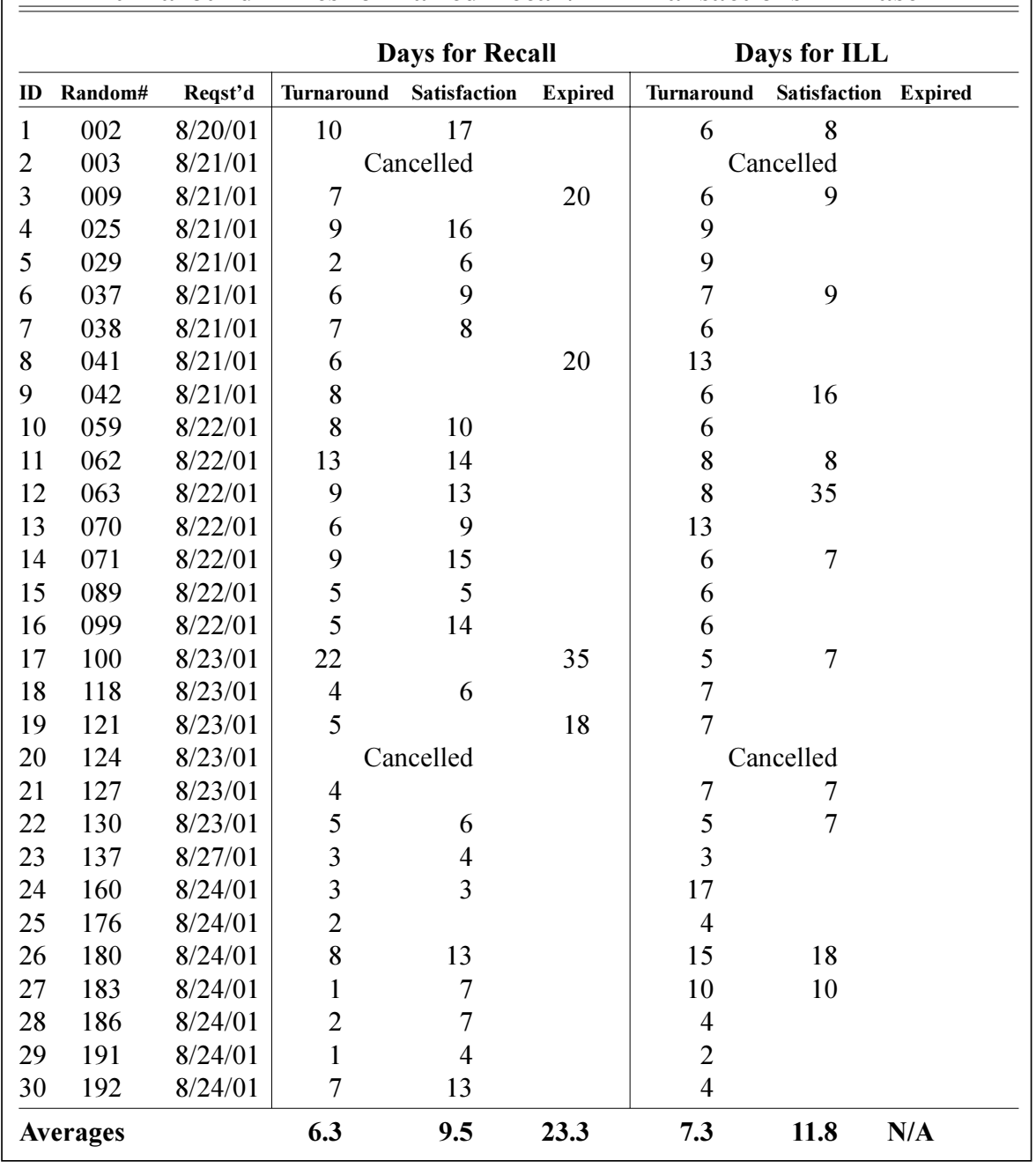




\begin{tabular}{|c|c|c|c|c|c|c|}
\hline \multicolumn{7}{|c|}{$\begin{array}{c}\text { TABLE } 4 \\
\text { Turnaround Times For the Eight Perfectly Paired Recall/ILL } \\
\text { Transactions in Phase } 2\end{array}$} \\
\hline \multirow[b]{2}{*}{ ID } & \multirow[b]{2}{*}{ Random \# } & \multirow[b]{2}{*}{ Reqst'd } & \multicolumn{2}{|c|}{ Days for Recall } & \multicolumn{2}{|c|}{ Days for ILL } \\
\hline & & & Turnaround & Satisfaction & Turnaround & Satisfaction \\
\hline 1 & 002 & $8 / 20 / 01$ & 10 & 17 & 6 & 8 \\
\hline 6 & 037 & $8 / 21 / 01$ & 6 & 9 & 7 & 9 \\
\hline 11 & 062 & $8 / 22 / 01$ & 13 & 14 & 8 & 8 \\
\hline 12 & 063 & $8 / 22 / 01$ & 9 & 13 & 8 & 35 \\
\hline 14 & 071 & $8 / 22 / 01$ & 9 & 15 & 6 & 7 \\
\hline 22 & 130 & $8 / 23 / 01$ & 5 & 6 & 5 & 7 \\
\hline 26 & 180 & $8 / 24 / 01$ & 8 & 13 & 15 & 18 \\
\hline 27 & 183 & $8 / 24 / 01$ & 1 & 7 & 10 & 10 \\
\hline \multicolumn{3}{|c|}{ Averages } & 7.63 & 11.75 & 8.13 & 12.75 \\
\hline
\end{tabular}

around time. Because of the ample data already available, further sampling was not necessary to establish mean ILL turnaround times. The ILL unit has used data management software (initially SaveIt, later Clio) since 1995 to track this figure, calculated from the date the material is ordered by ILL to the date it is received in ILL. Turnaround time for the borrowing of books and other returnables has been fairly consistent over the past few years: In FY2000, the average turnaround time for loans (as opposed to copies) was 11.4 days. The figure dropped slightly to 11.0 in FY2001 and FY2002. In the first three months of FY2003 (July through September 2002), the average turnaround time dipped further to 9.2 days, although the overall average for the past three years remains close to eleven days.

Comparing these figures with the average turnaround time for recalls in phase 1 , there would appear to be little difference between recalling a book from a local colleague or requesting it from another library: twelve days average in the former case, eleven days in the latter. This discovery surprised some library staff, who generally had assumed it would require significantly more time to access another library's book than to recall a book held locally. This assumption had been the basis for the long-standing library policy that prohibited interlibrary borrowing of books owned by the ISU library, even if they happened to be checked out for the academic year.

Phase 1 data suggested that the recall and ILL services were fairly comparable in terms of both turnaround and satisfaction time performance. Phase 2 of the study attempted to test this finding in another way. Using a smaller, but paired, sample, phase 2 measured the delivery time of precisely the same book in the same time frame by two different library services. Like phase 1, phase 2 tracked both turnaround time and satisfaction time. The results in table 3 show the average figures to be very close for turnaround time: 6.3 days for recalls, 7.3 for ILL. The average figures for "pickup," or satisfaction, reflect, in part, the patron's timeliness in retrieving available materials. In the loosely paired study of twentyeight transactions, the 9.5-day average for recall satisfaction is somewhat lower than the 11.8-day average for ILL. But because so few ILL items were actually picked up (12 out of 30 ), the comparison is not as reliable. In the very small, but interesting, subset of eight perfectly paired transactions, the satisfaction time for recalls is only slightly lower than that for ILL-11.8 and 12.8 days, respectively.

A further analysis of recall and ILL turnaround means was conducted with a twotailed $\mathrm{t}$ test, which demonstrated that there 
was no statistically significant difference between the means of the two samples with regard to both turnaround and satisfaction time. This provides further support for the initial finding that recall and ILL services are comparable in providing timely access to books at Iowa State.

\section{Conclusions and Recommendations}

Data from the current study can tell how well these two core functions-the circulation recall and the ILL borrowing transaction-are "performing," in both absolute and relative terms, with regard to timeliness. The data also provide a valuable baseline for future studies and comparisons. In the months following this study at Iowa State, for example, library staff implemented an electronic recall request form linked to the online library catalog, which obviates the need for a physical trip to the library to initiate a recall and is already in use by some 70 percent of requestors. In the upcoming semester, the library also will replace all printed patron correspondence, including recall and availability notices, with e-mail, further reducing the time required for patron notification and response. Together, these changes should appreciably reduce the average turnaround time for recalls. But will that be the case? Data from follow-up studies, measured against the current baseline figures, will provide the answer.

The data also can provide information on patron perceptions, attitudes, expectations, and behavior regarding these and other library services, particularly when the data can be supplemented with direct patron input. Surveys and focus groups, for example, can yield valuable insights into patrons' perceptions of the timeliness of various library services. However, neither performance data nor patron perceptions provide a complete picture of this issue. In fact, research suggests that, for at least some library services, perceptions of timeliness are based on much more than actual delivery time. ${ }^{40}$ The impact of patron attitudes, assumptions, and behavior on book availability, a topic beyond the scope of this paper, has fascinated librarians for decades. ${ }^{41}$ To understand these attitudes, test these assumptions, and conceivably shape this behavior, data such as those from the present study provide an important piece of the puzzle.

Certainly, the data suggest specific changes that might easily be made to existing policy. Given the average turnaround time for a "single" recall (9.6 days in phase $1 ; 6.3$ days in phase 2) and an ILL borrowing transaction (11 days), it appears reasonable to continue recalling locally owned books from local patrons and borrowing unowned books from other libraries. However, when a second recall is placed on a book, average turnaround time is likely to increase to almost sixteen days (based on phase 1 data), suggesting that the book could indeed be acquired more quickly via ILL despite local ownership. The ISU library has therefore begun to explore possible means (both systems and work flow based) to automatically refer second (and subsequent) recalls from the circulation desk to the ILL office.

Another policy change affects users who, intentionally or otherwise, directly submit ILL requests for books owned by the ISU library. In the past, ILL staff would routinely notify the user, by e-mail, of the item's call number and location, regardless of its actual availability. (The user was also informed of the library's fee-based document delivery service, which delivers a library-owned item to the requestor's home or office for a nominal fee.) Under the new policy, if the book is available on the shelf, the patron still receives e-mail notification of local availability. However, if the book is checked out or already recalled, ILL staff automatically borrow the book from another library/supplier. As a precaution, circulation records are verified first to make sure that the requestor is not the person who has borrowed or recalled the locally owned copy.

Some may question the library's ongoing reluctance to simply borrow a requested book via ILL, even if it is locally held and presumed to be on the shelf. One reason is obvious: The library already has 
a fee-based service in place to deliver ISUowned material to the offices and homes of its users. This value-added service, which provides a small, but steady, revenue stream for the library, could be seriously undercut if its subsidized ILL service began to offer free alternatives. A more obvious reason, generalizable to other libraries, is cost. According to the ARL study, the mean cost for an ILL-borrowing transaction in research libraries is $\$ 18.35 .{ }^{42}$ Circulation costs, in general, are reportedly much lower. In 1985, Pat Weaver-Meyers, Duncan Aldrich, and Robert A. Seal determined the mean cost of charging/renewing a book to be just $\$ 0.24$, although the cost for a recall transaction would be considerably higher and both would need to be adjusted for inflation. ${ }^{43}$ Circulation costs, of course, are just the tip of the "investment iceberg" for items permanently owned by a library, considering the additional costs of selecting, acquiring, cataloging, binding, marking, shelving, and continuously storing a monograph. ${ }^{44}$ As library funding continues to shrink, interservice cost comparisons will be essential to effective program planning and fiscal management. Unfortunately, cost data are not widely available for services other than ILL, and additional research is needed. ${ }^{45}$ One possible follow-up to the present study is to determine the actual cost of a recall based on local systems and work flow.

The scrutiny and comparison of the ISU library's recall and ILL processes impressed upon the authors the similarity of work flows involved. Both processes involve receiving a request, logging and tracking the request online, "ordering" (so to speak) and receiving the requested item, notifying the requestor of its availability, holding the item for a designated time, and checking the item out to the requestor. The concepts and terminology regarding delivery speed also were surprisingly similar: The turnaround and satisfaction times normally associated with ILL could be easily adapted to the recall function.

The final conclusion drawn by the authors is that ILL provides a reasonable alternative to the recall process under certain circumstances. For whatever reason, librarians and library literature-quick to recognize ILL as the preferred means of accessing what a library doesn't ownhave seldom considered ILL's potential in expanding access to material the library does own. To compensate for books being checked out when needed by patrons, librarians typically adjust their circulation policies or collection development practices, shortening loan periods or acquiring multiple copies of popular books. The present study suggests that ILL might be an effective, supplementary means of increasing book availability, particularly the availability of what Allen Kent referred to in 1979 as the "kernel of constantly used items," a concept still familiar to most academic libraries. ${ }^{46}$ These are the books that seldom, if ever, can be found on the shelf but, instead, exist in a perpetual state of transit from reserve operations to recall queues to ILL lending and back. In the shadow of the serials funding crisis that now preoccupies almost every academic library administrator, Charles Hamaker has urged librarians to consider the collateral damage to monograph collections. ${ }^{47}$ He has written: "One of the major casualties of what have been called the 'Serial' wars has been access to books in North America's academic and research libraries." ${ }^{48}$ In his call for a more sophisticated "calculus of collection development," Hamaker has suggested repeatedly that circulation data, including time series data, may be a key factor in the wise expenditure of limited monograph funds. ${ }^{49}$ Similarly, Albert Henderson's proposed "collection failure quotient" (CFQ), based on the ratio of ILL borrowing to local collection size, is another dynamic indicator that tells much about collection performance but, in and of itself, cannot assess failures in the timeliness of availability. ${ }^{50}$ As librarians work to create more effective, holistic models for developing, maintaining, and providing timely access to monograph collections, studies such as the present one provide one small, but useful, building block. 


\section{Notes}

1. Michael Rogers, "Loans \& Groans," Library Journal 124 (Oct. 1, 1999): 67-68.

2. Patricia Davitt Maughan, "Library Resources and Services: A Cross-Disciplinary Survey of Faculty and Graduate Student Use and Satisfaction," Journal of Academic Librarianship 25 (Sept. 1999): 354-66.

3. In the fifteen years between 1986 and 2001, the volume of serial and book purchasing by ARL institutions shrank by 5 percent and 9 percent, respectively. At the same time, the number of faculty and students at ARL institutions grew by 15 percent and 14 percent, respectively. Supply and Demand in ARL Libraries, 1986-2001, available online from http://www.arl.org/stats/ arlstat/graphs/2001/2001t3.html.

4. Merri A. Hartse and Daniel R. Lee, "Changing Circulation Policies at an ARL Library: The Impact of Peer Institution Survey Data on the Process," Collection Management 17 (1992): 133-48.

5. Michael H. Buckland, Book Availability and the Library User (New York: Pergamon, 1975), xi.

6. Ibid., 6. Richard Trueswell, of course, had published his infamous $80 / 20$ rule only six years earlier. See Richard Trueswell, "Some Behavioral Patterns of Library Users: The 80/20 Rule," Wilson Library Bulletin 43 (1969): 458-61.

7. Ibid., 70 .

8. Daniel Gore, “Let Them Eat Cake While Reading Catalog Cards: An Essay on the Availability Problem," Library Journal 100 (Jan. 15, 1975): 93-98.

9. Ibid., 98.

10. Paul B. Kantor, "Availability Analysis," Journal of the American Society for Information Science 27 (Sept.-Oct. 1976): 311-19; Tefko Saracevic, William M. Shaw Jr., and Paul B. Kantor, "Causes and Dynamics of User Frustration in an Academic Library," College \& Research Libraries 38 (Jan. 1977): 7-18.

11. Saracevik, Shaw, and Kantor, "Causes and Dynamics of User Frustration in an Academic Library," 15.

12. John Mansbridge, "Availability Studies in Libraries," Library and Information Science Review 8 (1986): 299-314.

13. Ibid., 305.

14. Ibid., 304.

15. Ibid., 299.

16. Terry Ellen Ferl and Margaret G. Robinson, "Book Availability at the University of California, Santa Cruz," College \& Research Libraries 47 (Sept. 1986): 501-8.

17. Anne C. Ciliberti, Mary F. Casserly, Judith L. Hegg, and Eugene S. Mitchell, "Material Availability: A Study of Academic Library Performance," College \& Research Libraries 48 (Nov. 1987): 513-27.

18. Eugene S. Mitchell, Marie L. Radford, and Judith L. Hegg, “Book Availability: Academic Library Assessment," College \& Research Libraries 55 (Jan. 1994): 47-55.

19. Ibid., 52-53.

20. Anne Ciliberti, Marie L. Radford, Gary P. Radford, and Terry Ballard, “Empty Handed? A Material Availability Study and Transaction Log Analysis Verification," Journal of Academic Librarianship 24 (July 1998): 282-89.

21. Ibid., 284, 286.

22. N. A. Jacobs, "The Evaluation and Improvement of Book Availability in an Academic Library," New Review of Academic Librarianship 1 (1995): 41-55.

23. Robert Goehlert, "Book Availability and Delivery Service," Journal of Academic Librarianship 4 (Nov. 1978): 368-71; and "The Effect of Loan Policies on Circulation Recalls," Journal of Academic Librarianship 5 (May 1979): 79-82.

24. Goehlert, "Effect of Loan Policies."

25. Thomas J. Waldhart, "Performance Evaluation of Interlibrary Loan in the United States: A Review of Research," Library and Information Science Research 7 (1985): 313-31.

26. Joan Stein, "Measuring the Performance of ILL and Document Supply: 1986 to 1998," Performance Measurement and Metrics 2 (2001): 11-72.

27. Ibid., 32.

28. Mary K. Sellen, "Turnaround Time and Journal Article Delivery: A Study of Four Delivery Systems. Ariel, Courier, Mail and Fax," Journal of Interlibrary Loan, Document Delivery \& Information Supply 9 (1999): 65-72.

29. John Budd, "Interlibrary Loan Service: AStudy of Turnaround Time," RQ 26 (fall 1986): 75-80.

30. Linda L. Phillips, Nancy Dulniak, Tisa Houck, and Biddanda P. Ponnappa, "Interlibrary Loan Turnaround Time: Measuring the Component Parts," Journal of Interlibrary Loan, Document Supply E Information Supply 9 (1999): 97-119. 
31. Kimberly A. Burke, "Checking Up on the Joneses: Using Fill Time Data to Improve Interlibrary Borrowing at New York University," Journal of Interlibrary Loan, Document Delivery $\mathcal{E}$ Information Supply 10 (1999): 19-30.

32. Pat L. Weaver-Meyers and Wilbur A. Stolt, "Delivery Speed, Timeliness and Satisfaction: Patrons' Perceptions about ILL Service," Journal of Library Administration 23 (1996): 23-42.

33. Mary E. Jackson, Measuring the Performance of Interlibrary Loan Operations in North American Research $\mathcal{E}$ College Libraries (Washington, D.C.: Association of Research Libraries, 1998).

34. Sue O. Medina, "Network of Alabama Academic Libraries: Interlibrary Loan Turnaround Time Survey," Southeastern Librarian 38 (fall 1988): 105-7.

35. Lee-Allison Levene and Wayne Pedersen, "Patron Satisfaction at Any Cost? A Case Study of Interlibrary Loan in Two U.S. Research Libraries," Journal of Library Administration 23 (1996): 55-71.

36. Jackson, Measuring the Performance of Interlibrary Loan Operations in North American Research $\mathcal{E}$ College Libraries, ix.

37. Weaver-Meyers and Stolt, "Delivery Speed, Timeliness and Satisfaction."

38. Johanna E. Tallman, "The Impact of the OCLC Interlibrary Loan Subsystem on a Science Oriented Academic Library," Science and Technology Libraries 1 (winter 1980): 27-34; A. T. Dobson, P. P. Philbin, and K. B. Rastogi, "Electronic Interlibrary Loan in the OCLC Library: A Study of Its Effectiveness," Special Libraries 73 (1982): 12-20; Jackson, Measuring the Performance of Interlibrary Loan Operations in North American Research $\mathcal{E}$ College Libraries, 24; and Burke, "Checking Up on the Joneses," 28-29.

39. Maurice B. Line, Measuring the Performance of Document Supply Systems (Paris: General Information Programme and UNISIST, UNESCO, 1987).

40. See, for example, Wilbur Stolt, Pat Weaver-Meyers, and Molly Murphy, "Interlibrary Loan and Customer Satisfaction: How Important Is Delivery Speed?" in Continuity E Transformation: The Promise of Confluence: Proceedings of the Seventh National Conference of the Association of College and Research Libraries, Pittsburgh, Pennsylvania, March 29-April 1, 1995, ed. Richard AmRhein (Chicago: ACRL, 1995), 365-71. See also, Weaver-Meyers and Stolt, "Delivery Speed, Timeliness and Satisfaction;" and Levene and Pedersen, "Patron Satisfaction at Any Cost?"

41. As early as 1917, for example, Thomas P. Ayer studied the effect of perceived over- or undersupply of material in a reserved book room, demonstrating that students perceiving that multiple copies of a book are readily available wait until the last minute to attempt to borrow it, thus compressing the period of demand into a very small window of availability. See Thomas P. Ayer, "Duplication of Titles for Required Undergraduate Reading," Library Journal 42 (May 1917): 356-58.

42. Jackson, Measuring the Performance of Interlibrary Loan Operations in North American Research $\mathcal{E}$ College Libraries, ix.

43. Pat Weaver-Meyers, Duncan Aldrich, and Robert A. Seal, "Circulation Service Desk Operations: Costing and Management Data," College E Research Libraries 46 (Sept. 1985): 418-31.

44. An in-house study now several years old at the Virginia Tech Library, for example, established the total cost for purchase and shelving monograph volumes at \$106 each and the total cost for purchase and shelving serial volumes at \$181 each. Cited in Charles B. Lowry, "Resource Sharing or Cost Shifting?-The Unequal Burden of Cooperative Cataloging and ILL in Network," College E Research Libraries 51 (Jan. 1990): 11-19.

45. In 1992, Karen S. Lange and Linda D. Tietjen proposed an outline of categories in which research and longitudinal studies were needed in the area of access services. First on their list were studies at the policy, operational, and procedural level for circulation functions such as fines, overdues, loan periods, and recalls. Unfortunately, little research has ensued in these areas. See Karen S. Lange and Linda D. Tietjen, "Management Challenges and Issues in Access Services Administration," Collection Management 17 (1992): 37-61.

46. Allen Kent et al., Use of Library Materials: The University of Pittsburgh Study (New York: Marcel Dekker, 1979), 16.

47. Charles Hamaker, "The Least Reading for the Smallest Number at the Highest Price," American Libraries 19 (Oct. 1988): 764-67; and "Toward a Calculus of Collection Development," Journal of Library Administration 19 (1993): 101-23.

48. _ـ "Toward a Calculus of Collection Development," 105.

49. See, for example, Charles Hamaker, "Management Data for Selection Decisions in Building Library Collections," Journal of Library Administration 17 (1992): 71-97; "Some Measures of Cost-Effectiveness in Library Collections," Journal of Library Administration 16 (1992): 57-69; "Time Series Circulation Data for Collection Development or: You Can't Intuit That," Library Acquisitions: Practice E Theory 19 (1995): 191-95; and "Redesigning Research Libraries: First Step toward the $21^{\text {st }}$ Century," Journal of Library Administration 22 (1996): 33-48.

50. Albert Henderson, "The Library Collection Failure Quotient: The Ratio of Interlibrary Borrowing to Collection Size," Journal of Academic Librarianship 26 (May 2000): 159-70. 